\title{
The Maiden and the Wolf: Law, Gender, and Sexual Violence in Imperial Russia
}

\author{
Katherine Pickering Antonova and Sergei Antonov
}

In 1859 a young gentry woman accused a much older and wealthier Moscow nobleman of rape. The ensuing legal case is exceptionally detailed, with several characteristics that make it especially illustrative of imperial Russian legal practice, attitudes toward gender and social status, and ordinary life in Moscow. ${ }^{1}$ The case took place before court procedures became public in Russia, so it is without the scandal and public discussion that attended such trials in western contexts or in Russia after 1866. Aside from a handful of high officials who reviewed the case and court clerks who copied it, information about these events would be communicated solely through rumor. ${ }^{2}$ The case record is composed of a patchwork of sometimes contradictory narratives from dozens of individuals, including witnesses, family members, and officials, and because they were not under the scrutiny of the press, their testimonies are less self-consciously performative than they would have been in a public trial (though witnesses were still performing for the investigators).

By pure coincidence, the victim in this case was named Maria, traditionally connoting Russianness and femininity, while the accused happens to have been named Vul'f, a Russification of the German surname Wulf, meaning "wolf." It is thus irresistible to read the case as a kind of folktale: an all too familiar story about an innocent, virtuous maiden violated by the big, bad wolf. At the same time, the story casts other unavoidable allusions. The slow reveal in the case records of forensic evidence and shifting tides of witness testimony recall a detective story of the type then being developed. ${ }^{3}$ Finally, the Russian public of the mid-nineteenth century might arguably have first seen this story through the lens of country versus city: on one hand innocence, associated with the village, with young womanhood, and with modesty and virtue, and on the other hand corruption, associated with cosmopolitanism

1. Tsentral'nyi istoricheskii arkhiv Moskvy (TsIAM), f. 16, op. 23, d. 440 (Delo o zhalobe dvorianki M. Il'inoi na iznasilovanie ee nadvornym sovetnikom Vul'fom), and f. 16, op. 23, d. 1409 (O nadvornym sovetnike Nikite Petrove Vul' fe). Below these two cases are cited by their file numbers only.

2. No single case can explain the workings of an entire legal system; that said, imperial-era legal professionals found this case illustrative. Soon after the 1864 Reform was implemented, a multi-volume selection of pre-reform cases included a short account of the Vul'f case, omitting important details that would have attracted attention from the public. Aleksandr D. Liubavskii, Russkie ugolovnye protsessy, vol. II (St. Petersburg, 1867), 226-36.

3. For example by Edgar Allan Poe and Émile Gaboriau. These works were translated into Russian, but this "lens," unlike the other two, is used more for comparison to western conceptions of police investigation and justice that inform historiographical expectations. 
in general and the city in particular, specifically with dishonesty, craftiness, and sexual vice. This article will explore the case through each of these three lenses and argue that each can help us to see different ways the ordinary, real Muscovites involved formed coherent narratives of their experiences, many of which were new to the rapidly-modernizing Moscow of that time. The images these individuals consciously and unconsciously chose to shape their stories are indicative, we argue, of how real-life Muscovites conceptualized gender, justice, and the urban and domestic spaces they inhabited.

A few years before Russia's Judicial Reform of 1864 was approved and implemented, this orphaned young woman of modest but respectable origins, Maria Prokofievna Il'ina, took a great risk when she accused Nikita Petrovich Vul'f, a retired civil-service official, of raping her. Maria had only an uncle and aunt, living in the provinces and without powerful personal connections, to support her. By comparison, Vul'f was a man of the world: at age thirty-nine, he was retired from the civil service with Class 7 (of 14) on the Table of Ranks, he owned 120 serf "souls" in Tver' Province, and his brother ranked two notches higher and ran the Moscow Provincial Treasury. ${ }^{4}$ In such a situation of unequal power and influence, even today it would be uncommon for a young woman to report a rape, or if she reported it, to successfully achieve prosecution of her attacker. In mid-nineteenth century Europe such outcomes were more surprising still, especially for a young lady whose social status was defined by property ownership as the Russian noble estate was, since her marriageability would be undermined by an accusation of rape regardless of whether she was believed.

In Russia as in western legal systems, the law was slanted so that rapewhile a serious criminal offense-was difficult to prove and unlikely to result in punishment even when everyone involved was convinced of the rapist's guilt. The outwardly respectable male voices of perpetrators were given extensive authority over any female voice, especially that of a woman without influential male connections. ${ }^{5}$ Rape investigations and trials scrutinized the victim's character, reputation, and conduct during the attack, assuming, in the words of a prominent Russian defense attorney from the post-reform era, that "a woman's slightest hesitation ... makes her an accomplice to the crime because it informs the man that he is being resisted for form's sake only,

4. TsIAM, f. 16, op. 23, d. 1409, 1. 29 ob., 33, 39 ob.

5. The most significant issues in the literature on nineteenth-century rape were differences in class and race/ethnicity between accused and accuser, on one hand, and newspaper and public perceptions of such cases, on the other. The literature on sexual violence in imperial Russia is still in its infancy; see Laura Engelstein, "Gender and the Juridical Subject: Prostitution and Rape in Nineteenth-Century Russian Criminal Codes," The Journal of Modern History 60, no. 3 (September 1988): 472-78, Alexandra Oberländer, "Shame and Modern Subjectivities: The Rape of Elizaveta Cheremnova," in Mark D. Steinberg and Valeria Sobol, eds., Interpreting Emotions in Russia and Eastern Europe (DeKalb, 2011), 82-101; and Alexandra Oberländer, Unerhörte Subjekte: Die Wahrnehmung sexueller Gewalt in Russland, 1880-1910 (Frankfurt am Main, 2013). Engelstein's overview of the law on nineteenth-century rape is discussed below; Oberländer's work examines cases from after the 1864 Reform and focuses on jury trials and newspaper treatments of such cases. 
and invites him to continue his efforts." ${ }^{\text {B }}$ By contrast, sexual aggression in nineteenth-century men, as Carolyn Conley has noted, "was perceived as normal, healthy, and inevitable."7

In pre-reform imperial Russia, historians might also expect to see a police and legal system unequal to the task of investigating and prosecuting the crime. The imperial government did seek to restrain young men's sexuality and tended to punish their sexual misconduct severely, but potentially grave legal and administrative sanctions seem to have rarely applied to respectable, middleaged men. In any case, they were unable to reform a culture of elite-masculine violence that promoted ritualized and rather brutal physical assaults against fellow army officers or university classmates, as well as complete strangers, both women and men. ${ }^{8}$ While we might suppose that Maria Il' ina would garner the sympathy of the courts given the Orthodox Church's continued dominance of family law and the persistent cultural influence of early-modern understandings of feminine honor, pre-Reform courts were widely criticized for their lack of judicial autonomy, corruption, and cumbersome, archaic procedures. ${ }^{9}$ Similarly, tsarist police are assumed to be incompetent. ${ }^{10}$ Further, given that the facts revolved on the testimony of servants, some of them enserfed (with Emancipation also on the horizon), we might expect servants to refuse to testify, provide such self-protective testimony that it could not be relied upon, or simply not be taken seriously by the court because of their low social status and dependency on either the accused rapist or his accused accomplice.

Maria made her accusation immediately, however, and was believed by her guardian, Emilia Andreevna Podolskaia. ${ }^{11}$ The police carried out an assiduous investigation, and the courts considered the case with great seriousness. Servants in Maria's household universally supported Maria's story, while Vul' f's servants were silent or forgetful, suggesting that both sets of servants

6. Aleksandr Lokhvitskii, quoted in I. Nussbaum, Cherty iz zhizni prestupnikov (nabliudeniia ochevidtsa) (Zhitomir, 1900), 19.

7. Carolyn A. Conley, "Rape and Justice in Victorian England," Victorian Studies 29, no. 4 (Summer 1986): 519-34, 532.

8. Rebecca Friedman, Masculinity, Autocracy and the Russian University, 1804-1863 (New York, 2004), esp. 30-32 and 44-46; Irina Reyfman, Ritualized Violence Russian Style: The Duel in Russian Culture and Literature (Stanford, 1999); see also Barbara Clements, Rebecca Friedman, and Dan Healey, eds. Russian Masculinities in History and Culture (New York, 2002).

9. For the most critical accounts, see Elise Kimerling Wirtschafter, "Russian Legal Culture and the Rule of Law," Kritika: Explorations in Russian and Eurasian History 7, no. 1 (Winter 2006): 61-70; Harriet Murav, Russia's Legal Fictions (Ann Arbor, 1998); Laura Engelstein, "Combined Underdevelopment: Discipline and the Law in Imperial and Soviet Russia," The American Historical Review 98, no. 2 (April 1993): 338-53; and John P. LeDonne, Absolutism and Ruling Class: the Formation of the Russian Political Order, 1700-1825 (Oxford, 1991), 179-235.

10. Robert J. Abbott, "Police Reform in the Russian Province of Iaroslavl, 1856-1876," Slavic Review 32, no. 2 (June 1973): 292-302, here 301. See also his "Police Reform in Russia, 1858-1878," (Ph.D. diss., Princeton University, 1971).

11. Podolskaia was a Catholic of minor provincial gentry background, a second lieutenant's wife. She had previously served as a housekeeper at a gymnasium in Kursk for nine years. See TsIAM, f. 16, op. 23, d. 1409, 1. 22 ob and 33 ob. Russia's Penal Code of 1845 required that rape be reported before the end of the day. Svod zakonov Rossiiskoi imperii, vol. 15 /2, art. 312 (St. Petersburg 1857). 
believed Maria and essentially cooperated in helping her to obtain justice despite the risks attached to involvement in a legal battle. ${ }^{12}$ The outcome also depended on physical evidence, which the police obtained and studied with reasonable competence. Ultimately, neither the physical evidence nor witness testimony added up to a conviction according to Russia's system of "formal proofs" in force before the reform of 1864, although the judges on each of three levels of the court hierarchy disagreed about Vul'f's guilt and reached opposing conclusions.

These considerable contradictions and surprising twists require explanation. We contend that the three imaginative scenarios discussed below offer a window into the mentalities of the accused, his victim, witnesses, and the state officials involved, offering the most plausible explanation for their actions. While historiographically surprising and defying stereotypes, the behavior of the individuals populating Il'ina's case makes sense in light of the anxieties of a time and place undergoing enormous upheaval: the Moscow lower-to-middling classes on the eve of the Great Reforms, in the middle of a state-driven effort to modernize and westernize the urban public.

Nineteen-year-old Maria Il'ina found herself in Moscow with only a barely-known family acquaintance as temporary guardian beginning on June $1,1859 .{ }^{13}$ Maria would later testify that she did not set foot outside Podolskaia's apartment in the eighteen days she lived there, and two servants would corroborate this assertion of maidenly propriety. It would not be surprising if Maria was intimidated by the chaotic urban space around her. Though born to a minor gentry family from Kursk province, after losing her parents she was educated in the Nikolaevsky Institute for Orphans in Moscow. The Institute was established in 1837 as part of the famous Imperial Orphanage to educate orphaned children of military officers and civil servants; it was carefully cloistered despite its Moscow location. ${ }^{14}$

Upon completion of her studies, Maria's aunt arranged for her expensive journey of several days to Kursk Province by requesting Podolskaia, who was from the same province and acquainted with Maria's family, to serve as guardian while the girl awaited her escort. Podolskaia was renting rooms from a priest, Nechaev. It was typical of nineteenth-century Moscow for those of middling ranks who could afford their own building to rent out rooms to people from equally respectable backgrounds, but often from a variety of cultures: clergy, students, minor officials, merchants, and sometimes gentry women on their own like Podolskaia. Priest Nechaev's building faced a monastery in the Sretenskaia district, in the so-called Earthen City to the north of the center.

12. According to Vul'f's servants, Vul'f's undergarments could not be accounted for during the week in question and they were all suspiciously unable to guess their master's whereabouts at any given time. See TsIAM, f. 16, op. 23, d. 440, 1. 10-10 ob.

13. TsIAM, f. 16, op. 23, d. 440, 1. 2-5 ob.

14. Orphanages were taken particularly seriously by the state since Catherine the Great and her Enlightenment-inspired impulse to use wellborn orphans as an experiment in molding young people in the state's image, to the state's purposes. On the Nikolaevskii Institute, for orphans of more modest backgrounds, see V. Selivanov, Obzor Moskovskogo vospitatel'nogo doma (Moscow, 1866), 29-38. On the Imperial Orphanage, see David L. Ransel, Mothers of Misery: Child Abandonment in Russia (Princeton, 1990). 
This was a lower-middle class but respectable neighborhood where residential buildings sat adjacent to small food shops, taverns, and inns. Podolskaia rented all or most of the building's second floor but occupied only two of the rooms, where she lived with a townswoman (meshchanka) cook from Orlov Province and a fifteen-year-old serf chambermaid, Ekaterina. Four other rooms were supposed to be sub-let but at the time only one was occupied. The entry-hall led to a staircase containing the door to another set of rooms, also rented by Podolskaia but unoccupied and referred to as the "empty half."

While Maria was staying with Podolskaia, she was made uncomfortable by visits from Nikita Vul'f, who had become acquainted with Podolskaia at a masquerade only a few months earlier. Maria claimed that he visited three or four times during her stay, and-emphasizing that she had done nothing to encourage him-she later testified that on these occasions Vul' $\mathrm{f}$ had been "free" and "insolent" with her, squeezing her hands, entering her bedroom, inviting her to a popular pleasure garden called the Hermitage, and even "at one time want[ing] to kiss" her. She said she had complained to her guardian and Podolskaia had reprimanded Vul'f for his insolence and admitted that he was "wild and reckless," though she continued to allow his visits.

By June 18, 1859, Maria's chaperone from Kursk, a serf nanny, had arrived. On that day, however, Vul'f visited again. He came, he said, to escort Maria and Podolskaia to the Hermitage. They demurred, but he persisted, offering to take just Maria, but again she refused. He left. Soon after Vul' f's departure, according to her own account, Maria asked Podolskaia for newspapers to read, and Podolskaia said they were in the "empty half." Maria testified that she walked out to the landing, unlocked the door to the "empty half," and suddenly saw Vul'f on the stairs. As she entered, he ran after her. He embraced her, she struggled, and he locked the door behind them. Maria claimed that Vul'f's eyes were wild, and so she struggled out of his arms and banged on the door, shouting for help, but no one came. She begged, cried, and berated Vul'f to no avail. He then pushed her between a dresser and the bed, "so strongly that she almost lost consciousness." He picked her up, at which point she would later say she did momentarily lose her senses while he lifted her to the bed, where he raped her. Afterwards he begged her to tell no one and promised to go to her village with her and "take her upon himself," apparently meaning he would provide for her, but not mentioning marriage. Maria did not reply, and Vul' $f$ left. Maria then immediately ran to Podolskaia, and both Podolskaia and the chambermaid Ekaterina testified that Maria was visibly frightened, red, and disheveled. Ekaterina stated that about eight minutes had passed since Maria had left to fetch the newspapers. Maria told Podolskaia that Vul'f had raped her. Podolskaia checked Maria's undergarment and found that it showed evidence that sexual intercourse had taken place. ${ }^{15}$

Podolskaia first left to consult her daughter about how to proceed, then brought Maria to the Moscow Police Chief. Vul'f was summoned to the police on the morning of June 19, then he was interrogated, his apartment was searched, and his servants were questioned on June 20. By June 21, he was arrested and remained in custody for the remainder of the court procedure, which would continue until the end of February of the following year. Vul'f

15. For Maria’s testimony, see TsIAM, f. 16, op. 23, d. 440, 1. 2-3ob. 
flatly denied Maria's account and maintained this denial to the end, even during a face-to-face courtroom encounter in which Maria begged him to admit to his deed, saying he should admit that his "passions" had been "stronger than himself" but that he should not compound his error by further punishing a person he had already "insulted."16

Although Maria Il' ina could not claim great value on the marriage market even before her defloration, by accusing Vul'f of rape she must have lost any chance of pursuing her immediate plan to be a governess. A logical alternative would be to induce Vul'f to marry Maria. In 1860, Moscow courts were processing another case of rape that involved a young townswoman, the ward of a respectable merchant, Ivan Kuzmin. After being raped by a store clerk with whom she had briefly run away, the criminal investigation stimulated some behind-the-scenes bargaining that ended with the two young people jointly petitioning the court to discontinue the case because they agreed to be married (and her guardian agreed to provide a dowry). Judging from the energy with which the merchant petitioned the court, he was the driving force behind the settlement. ${ }^{17}$ In the Il'ina case, there were two considerations that possibly prevented marriage. One was that Maria could not expect to receive a dowry: her uncle was apparently not wealthy enough. Second, although the Trustees of the Imperial Orphanage included powerful people such as Prince Nikolai Ivanovich Trubetskoi and General Dmitry Akhliostyshev, they appear to have been more concerned with the Institute's prestige-which required Vul'f's prosecution-than with Maria's personal fate and were in any case too highly-ranked to become personally involved in negotiations. ${ }^{18}$

Another possibility was to induce Vul'f to make a payment to Maria to secure her immediate future. Indeed, the mid-level court that eventually convicted Vul' $\mathrm{f}$ of rape also ordered his property to be used to provide an allowance for Maria until her marriage. Other cases from the mid-nineteenth century involved bargaining for compensation with victims-whether lowly peasants or urban nobles-either demanding or being offered favors or cash payments. ${ }^{19}$ Presumably, Vul'f could have been persuaded to raise a similar sum

16. TsIAM, f. 16, op. 23, d. 1409, 1. 23-23ob.

17. TsIAM, f. 16, op. 23, d. 1342 (Delo ob iznasilovanii Moskovskoi meshchanki Marii Pavlovoi volokolamskim kupecheskim synom Pavlom Glebovym), (1860).

18. As historians of sexual violence in Victorian Britain have also noted, rape cases had far better outcomes when victims were assisted by well-to-do patrons. Carolyn Conley, The Unwritten Law: Criminal Justice in Victorian Kent (Oxford, 1991); Clive Emsley, Crime and Society in England, 1750-1900 (New York, 2005); Martin J. Wiener, Men of Blood: Violence, Manliness, and Criminal Justice in Victorian Britain (Cambridge Mass., 2006).

19. In March 1859, a 24-year old peasant man from a village in the Ruza district bargained with the mother of his victim, a 20 -year old deaf and "feeble-minded" peasant woman. His offer of ten silver rubles was not accepted, resulting in legal proceedings, TsIAM, f. 50, op. 4, d. 5546. In 1858, civil servant Mikhail Snegiriov, a general's son, was accused of raping his teenage serf chambermaid, but was able to induce the victim to drop the charges by promising not to treat her severely and to send her back to the village and her parents. TsIAM, f. 50, op. 4, d. 5547. In 1863, prominent serf owner and cavalry officer Ivan Mikhailovskii-Danilevskii was accused of raping Praskovia Lebedeva, the wife of his former estate manager. The husband, later accused of bribing witnesses and other misconduct, apparently tried to induce the accused to pay 500 rubles to settle the case. TsIAM, f. 50, op. 4, d. 7944. 
of money. ${ }^{20}$ We know from the case record that Vul'f returned to Podolskaia's apartment after the attack and offered Maria a box of candy, causing an indignant reaction..$^{21}$ If this was an attempt to begin a negotiation, there is no evidence of bargaining taking place, at least not with Maria. However, in the course of the investigation Podolskaia's testimony became more sympathetic to Vul'f: she became somewhat hostile to Maria and eventually even served as Vul'f's surety when he was freed from prison. Moreover, the fact that Vul'f was completely acquitted during the lower-court trial, with judges ignoring not only the evidence against him but also the influence of the Trustees of the Orphanage, is unusual and suggests some collusion, since it was common for lower courts to give out more severe sentences in serious criminal cases knowing that there would be a mandatory review by the upper-level court.

Regardless of any extra-judicial maneuvering, as soon as the rape was reported to the police, officials acted quickly. This urgency may be traceable to Maria's association with a school under Nicholas I's direct patronage. Certainly, her uncle assumed this when he appealed to the Orphanage to act on her behalf, and it did so, sending an observer to witness all the proceedings who also attempted to give himself power of attorney to act for her. ${ }^{22}$

Russian courts in this period-still affected by religious influences on the law-were primarily oriented toward controlling women's sexuality and even physical mobility, consistently upholding a traditional right of husbands and fathers in matters of divorce, abandonment, or crimes related to sexual transgression by women, while at the same time energetically upholding Russian women's extensive property rights. ${ }^{23}$ Such attitudes originated in early modern legal customs, where elite women, who were perceived to have more elevated spirituality and less worldliness, were therefore more in need of male protection, and assaults against their honor could be seen as greater than the debasement of a man. ${ }^{24}$ Early modern elite women in Russia were generally believed when they made accusations of rape and defended their interests in court. ${ }^{25}$ Maria Il'ina conformed, or at least appeared to conform, to the same

20. It is surprising that they did not involve the gendarmes as mediators. See, for example, the case of Matvei Volkov, a civil servant from Petersburg, who complained about the rape of his sister by his acquaintance, another official, Stanislav Vysotsky, in 1871. GARF f. 109, op. 101 d. 615. In that case, Vysotsky refused to negotiate and the case proceeded to trial.

21. TsIAM, f. 16 , op. 23 , d. $440,1.3$ ob., 8.

22. TsIAM, f. 16, op. 23, d. 440, 1. 12ob.-13.

23. See William G. Wagner, Marriage, Property, and Law in Late Imperial Russia (Oxford, 1994); Barbara Alpern Engel, Breaking the Ties That Bound: The Politics of Marital Strife in Late Imperial Russia (Ithaca, 2011); and Michelle Lamarche Marrese, A Woman's Kingdom: Noblewomen and the Control of Property in Russia, 1700-1861 (Ithaca, 2002).

24. See especially Isolde Thyrêt, Between God and Tsar: Religious Symbolism and the Royal Women of Muscovite Russia (DeKalb, 2001) and Valerie A. Kivelson and Robert H. Greene, eds., Orthodox Russia: Belief and Practice under the Tsars (University Park, 2003).

25. Daniel Kaiser, "'He Said, She Said': Rape and Gender Discourse in Early Modern Russia," Kritika: Explorations in Russian and Eurasian History 3, no. 2 (Spring 2002): 197-216, esp. 206. Technically rape cases at that time should have been prosecuted by the Church, though in reality they were often tried in the secular courts as crimes of physical assault, and this practice was formally legislated under Peter the Great. See Nancy Shields Kollmann, Crime and Punishment in Early Modern Russia (Cambridge Eng., 2015), 220. 
ideals of femininity on which this system was based and thus her rape could be seen as a violation not only of her own person, but of the notion of feminine modesty and domesticity, the latter concept merging early-modern spiritual ideals into a nineteenth-century cultural context.

Given that Russia's legal development is habitually compared-unfavorably-with Anglo-American and other major western systems, a brief comparative discussion is necessary. Elsewhere in Europe at the time, women's presumed place in the home made rape difficult to prosecute unless it occurred in a public space and was perpetrated by a stranger. The concern was for protecting the status and respectability of men and male privilege over protecting female honor. In France, to convict a rapist of an adult victim the rape needed to have been witnessed and violence proved; even proof of violence alone was often not sufficient to convince juries. Common belief was that it was not even possible for one man alone to perpetrate a rape. ${ }^{26}$ In Victorian Britain convictions were more likely in rural areas, where privileged victims had family support (servants living in the country without their families had no such advantage), and younger women were more likely to succeed in seeing their rapists prosecuted. ${ }^{27}$ At the same time, since the victim's character and reputation were at the center of any rape trial, the surrounding community, if it turned against the victim, could pressure juries to acquit. ${ }^{28}$ And, while rape victims were more likely to be believed if the act took place in public or outdoors, victims were also likely to be seen as having invited the attack by placing themselves in danger. ${ }^{29}$ In British cases involving "respectable" men like Vul'f, when the evidence was sufficient that a case could not be dismissed, the charges were often lessened. ${ }^{30}$ The victim's status could also work in her favor, however: in Carolyn Conley's study of Victorian Kent, every case involving a "lady" went to trial, with an 87 percent conviction rate, as compared to only 43 percent when victims were domestic servants. ${ }^{31}$

Although rape had been a capital crime in Britain until 1841, its seriousness was probably due to the perception of women's virginity as essential to male inheritance. Paradoxically, the serious nature of the crime appears to have worked against women in that period, causing charges to be lessened or dropped when a high-status man's reputation was at stake. The role of male inheritance would have been lesser in Russia, where partible inheritance prevailed over male primogeniture and rules of coverture never appeared. At the same time, earlier industrialization, a larger middle class, and secularizing social transformations arguably made women more threatening to respectable

26. James M. Donovan, Juries and the Transformation of Criminal Justice in France in the Nineteenth and Twentieth Centuries (Chapel Hill, 2010), 104. This was a common myth also shared by the Aulic Court (the first-tier court that tried Vul'f), which requested Moscow's medical examiner to clarify whether Vul' $f$ could have held Il'ina and raped her at the same time.

27. Emsley, Crime and Society, 105-6.

28. Gwenda Morgan and Peter Rushton, Rogues, Thieves and the Rule of Law: The Problem of Law Enforcement in North-East England, 1718-1800 (London, 1998), 56.

29. Morgan and Rushton, Rogues, Thieves, 57.

30. Conley, The Unwritten Law, 83.

31. Conley, "Rape and Justice," 530. 
male British culture, which may account for the considerable difficulty British women had in obtaining justice in rape cases, or at least the lesser penalties high-status men often paid even if convicted. . $^{32}$

In the American antebellum South, propertied ladies were more protected and their movements and spheres of activity even more restricted than in imperial Russia, much less Victorian Britain or France. Southern men's honor was interconnected with that of their women, making even verbal insults against a woman a serious affair requiring a response. In this context, a woman who was raped or who had consensual sex outside of marriage was equally "erring" and her own blame was shared with the men who were presumed to have failed to control, protect, or avenge her and their honor. ${ }^{33}$ By contrast, Russian landowning women's spheres were at least sometimes much wider, and while notions of dishonor played a significant role, the insult did not attach to male protectors. ${ }^{34}$

From his initial interrogation, Vul'f's account of his activities on the day of the rape confirmed his arrivals and departures as claimed by the women of the Podolskaia household, but otherwise contradicted Maria's story. ${ }^{35} \mathrm{He}$ described his day after leaving Maria elaborately, with many confusing details involving a series of ordinary, mildly irritating errands. ${ }^{36}$ This narrative may have been designed to undermine what Maria described as his "halting, incoherent speech" and the "wild" fit of the rape. ${ }^{37}$ Assuming the court looked on rape as a crime of lust or passion rather than violence and control, as was

32. The obvious differences between Britain and Imperial Russia make direct comparison problematic. While there is substantial literature on rape around the nineteenth-century world, the literature on law and rape is far better developed in the Anglo-American context, so that it serves as the most detailed outside frame of reference. Since imperial Russian authorities and intellectuals continually compared themselves to such western powers, either unfavorably or while insisting on their place as a fellow great power alongside these countries, and since the "imperial social project" to transform Moscow that we refer to here was specifically defined in part as an attempt to make Moscow more like western capitals, London prominent among them, the comparison is not irrelevant. Finally, rape cases from mainland Britain do share some key features with the Russian case under discussion-urban settings, an absence of racial disparities, and notions of respectability and domesticity within a privileged, propertied class.

33. Bertram Wyatt-Brown, Southern Honor: Ethics and Behavior in the Old South (Oxford, 1982), 53-54. Thus, Wyatt-Brown points out that "rape constituted only one-half of one percent of all arraignments in antebellum South Carolina," which must be far lower than the actual incidence of rape (292). However, white southern women who consensually had sex with black men were incentivized to claim rape. Further comparisons to the antebellum South, often useful given pre-Reform Russia's similarly agricultural society based on unfree labor and vast wealth inequality, break down, since much of the contemporary concern and scholarly discussion considers how racial attitudes informed understandings of and prosecutions of rape cases. The same is true for many colonial societies.

34. On the wider roles sometimes played by Russian women property owners and the reasons for the difference, see Marrese, A Woman's Kingdom and for a microhistorical account of how women's property ownership affected roles and relationships in a single family, Katherine Pickering Antonova, An Ordinary Marriage: The World of a Gentry Family in Provincial Russia (Oxford, 2013).

35. TsIAM, f. 16, op. 23, d. 440, 1. 5 ob. -6 ob.

36. TsIAM, f. 16, op. 23, d. 1409, 1. 11 ob.

37. TsIAM, f. 16, op. 23, d. 440, 1. 3. 
likely in that period, Vul'f employed a good strategy by presenting himself as mildly amused by Maria yet distracted by other concerns.

When questioned about his earlier visits and when confronted in court with medical evidence and Maria's testimony, however, Vul'f's responses seem-apparently without his realizing it-to reveal him as certainly reckless and possibly a practiced rapist. Implicating Podolskaia, whom he would separately claim had loose morals, Vul'f testified that the guardian had laughed with him at Maria's embarrassment when he tried to kiss her hand. He admitted he had been inside the bedroom when Maria was absent, presumably visiting Podolskaia, because people "of insufficient means" often receive visitors in bedrooms, he claimed. ${ }^{38}$ This, too, reflected poorly on Podolskaia, since investigators and court officials were not impressed by Vul'f's airy explanation. They annotated the case file, saying: "Mr. Vul' $\mathrm{f}$ should have been asked how he, as a nobleman, and therefore possessing an education, could allow himself to enter the bedroom of a girl who received a good upbringing and, moreover, do so during his first visit; such action by Mr. Vul'f is not proper for a noble person who does not have some improper purpose." 39 Thus Vul'f's own account of his behavior demonstrated that he was not respectable. Podolskaia's failure to reprimand him suggested she was complicit. ${ }^{40}$ Further, when Vul'f was confronted with medical testimony in court, he opined that "as concerns the fact that Il'ina did not resist or scream while she was being raped ... this [suggests she was not raped] because ... to deprive a woman of her senses and hold her in an insensible state long enough [for a rape to occur] is impossible without the use of narcotics." ${ }^{41}$ This suspiciously confident and detailed conclusion contrasts strongly with the report from the police Medical Office, which examined her clothing-none of it torn-and concluded cautiously that the evidence neither confirmed nor undermined her claim of rape. Finally, but most damningly, while referring to Maria's testimony that she was conscious during the rape, Vul' $\mathrm{f}$ mentioned his wiping off her tears, a detail Maria had never mentioned. ${ }^{42}$

38. TsIAM, f. 16, op. 23, d. 1409, 1. 10 ob.

39. Ibid.

40. Despite Vul' $\mathrm{f}$ 's outward signs of respectability such as possession of land with serfs, leisure, and a highly-ranked brother, he was either poorly regarded to start with or lost his respectability during the criminal proceedings: there is no evidence of any friends, relatives, or acquaintances petitioning or testifying on his behalf. A procuracy official, Ogarev, noted that Vul'f was not well known because he only recently came to Moscow. TsIAM, f. 16, op. 23, d. 1409, 1.40 ob. Only the Marshal of the Nobility from Tver' Province, where his estate was, wrote to the Moscow governor with a request to learn about the charges against Vul'f. The Moscow governor emphasized the confidential (i.e., potentially damaging) nature of this information. TsIAM, f. 16, op. 23, d. 440, 1. 21-21 ob. After it was resolved to release Vul'f, only Podolskaia agreed to serve as his surety, i.e., to personally guarantee that he would remain in the city and appear in court whenever required. TsIAM, f. 16, op. 23, d. 1409, 1. 1 ob. Contrast this to Britain, where even after a rape conviction men were unlikely to lose their respectability, except in cases where they served time with lower-class offenders. See Emsley, Crime and Society, 106; Conley, "Rape and Justice," 528-30.

41. TsIAM, f. 16, op. 23, d. 1409, 1. 27-27 ob.

42. Ibid. 
Podolskaia's testimony is most notable for the many shifting claims she made over time, sometimes contradicting herself and often contradicting other witnesses in ways that make little sense. It is clear, at least, that Podolskaia was afraid and certainly lied in some parts of her testimony; what the court needed to decide was whether this behavior indicated that she was complicit in Vul'f's rape, or whether she was merely a negligent guardian. Podolskaia attempted to explain her acquaintanceship with Vul'f in respectable terms by specifying that the masquerade where they met was at the Noble Assembly, which Podolskaia attended with a Colonel Berg and a relative named Pomerantseva, apparently Mrs. Berg's companion..$^{43}$ Podolskaia claimed that Berg gave Vul'f her address, although both men later denied this. Other allegations made Podolskaia's shifting stories even murkier to the courts. Podolskaia's own daughter described her as a "rather experienced woman," a phrase with negative connotations in the original. ${ }^{44}$ Worse, Podolskaia's husband claimed that she was paid to "organize rendezvous at her home for objectionable purposes," that she had in the past, and continued at the time, to "turn her husband's serf girls to unseemly use" and that she herself "did not possess good morals." He had initiated proceedings through the Tver' Precinct to have his serf girls taken away from his wife, though this procedure was still underway. ${ }^{45}$ Podolskaia countered that her husband was living in a mental asylum in Khar'kov on a trial term, implying that his testimony could not be taken seriously. Indeed, it is possible that a rancorous husband took advantage of Podolskaia's predicament and invented his accusations as a means of discrediting her and freeing himself from the asylum. ${ }^{46}$ In any case, the policemen, clerks, and lawyers writing up the case presented Podolskaia very differently from Maria: she was clearly understood to be an experienced, urban woman, and that made her suspect.

Throughout the testimony there are repeated references to public entertainment venues: the masquerade where Podolskaia met Vul' $f$ and the Hermitage, a pleasure garden where Vul'f invited Podolskaia and Maria. Implicit in the mentions of these public spaces is a taint of danger and disreputable behavior. Although the masquerade was held at the Noble Assembly and thus restricted to elites, it probably retained its earlier air of disrepute so familiar to readers of Pushkin's Eugene Onegin, in which the large crowd created amorous opportunities for Muscovites and doubled as a marriage market for visiting provincial gentry. For Maria, even the invitation to the Hermitage was an insult: she consistently included it in the list of Vul'f's advances prior to June 18 that made her uncomfortable, and it was the excuse for his visit on the date that she accused him of raping her. With repeated references to her provincial origins and cloistered existence Maria was portraying herself, and was portrayed by witnesses, in contrast to Vul'f's association with the city, a dichotomy that recalls common literary and prescriptive press tropes of the time. 
The imperial orphanage and the public assembly both appeared in the eighteenth century and reflected Enlightenment values and the state's intention to mold individuals to its purposes. But whereas the orphanage sought to isolate middle-class youth from worldly corruption, the masquerade and the Hermitage were intrinsic to pre-emancipation Moscow as an "imperial social project" that aimed to produce an "enlightened" westernized city largely through encouraging a homogenized, middling social strata. Part of the state's goal was to raise the morals and manners of Muscovites by socializing them in safe public spaces, but, as Alexander Martin argues, the project was only intermittently and partially successful. The state was riven with anxiety about the dangers urbanization and westernization invited, even while craving prosperity and status. ${ }^{47}$ We argue that the courts' strong reaction to this case might reflect these fears of the risk involved in social transformation, exemplified by Vul'f's behavior. Though the obvious foreign associations of Vul'f's surname were not called out specifically in court records, this, too, may have contributed to officials' uneasiness at a period when Russian nationalism was being defined and given more emphasis by the state in its self-representation, amid fears of the immoral and disruptive aspects of urban, western culture. ${ }^{48}$

Compare the Il'ina case, for example, to another from pre-reform Moscow in which a young artisan's daughter was raped by a serf after attending a public entertainment with an older girlfriend who led her into a trap. In that case, the serf was acquitted despite the father's best efforts, the courts having taken a dim view of a young woman venturing into a public space unprotected and socializing with "dangerous," that is, lower-class youths. ${ }^{49}$ In 1850 , a case remarkably similar to Il'ina's involved a young student of Moscow's Yekaterininskii Institute (like the Nikolaevskii Institute, it was established to educate young noblewomen of modest means), who was staying briefly in the city with her mother and was raped by a retired cavalry officer, Kozlianinov, with the assistance of his friends and especially his relative, Emilia Fedorova. Fedorova acted as the young woman's chaperone and induced her to leave the house. Kozlianinov was much wealthier and better connected than Vul'f and was able to delay the investigation, even though the victim's mother complained verbally to the tsar in Peterhof and was assisted by the gendarmes. Kozlianinov ignored court-imposed restrictions on travel and even got married while the case was proceeding. Ultimately, the outcome was determined by the fact that the victim left her house voluntarily. ${ }^{50}$

Both crimes threatened the state's hopes for a moral and mannered middle class, but Maria Il'ina, by modestly staying at home, did not invite insult in the eyes of nervous upper-class officialdom; insult came to find her by way of Vul' f's invitation to the Hermitage. In English law, victims could be interpreted as having invited an attack by unwisely leaving the house without a

47. Alexander M. Martin, Enlightened Metropolis: Constructing Imperial Moscow, 1762-1855 (Oxford, 2013).

48. Richard S. Wortman, Scenarios of Power: Myth and Ceremony in Russian Monarchy, Vol 1: From Peter the Great to the Death of Nicholas I (Princeton, 1995).

49. TsIAM f. 50, op. 4, d. 3837. The girl's father was a British subject.

50. GARF f. 109, op. 83, d. 267. 
chaperone. ${ }^{51}$ The rapes most likely to be successfully prosecuted, however, were those in which a lady was attacked by a lower-class stranger in public (70 percent of convictions). ${ }^{52}$ In Russian law, judges were not supposed to take the venue of an attack into consideration and this may have helped Maria, since she was attacked by an acquaintance inside the building where she was living. It seems likely, however, that in a larger sense the peculiar uncertainties of Muscovite officialdom about the state project to encourage middle-class public sociability was influential.

In still another sense, concerns about public and private spaces enter this case through the peculiar layout of the building where Podolskaia and Maria lived and through the role of the servants as witnesses. ${ }^{53}$ Podolskaia's two servants, her neighbor's servant Ivanov, and the Kursk nanny Sofia Grigorievna all stated (predictably) that they never witnessed anything prejudicial against Podolskaia, and-strikingly-that none of them had ever opened the empty half of the second floor for any purpose, nefarious or otherwise. The cook offered little more, stating that she spent most of her time in the kitchen, thus disclaiming any knowledge of the "empty half." The chambermaid and the nanny both corroborated Maria's testimony, although neither servant was able (or willing) to add much detail. ${ }^{54}$ Key eyewitness testimony came from Evsei Ivanov, however, manservant to Podolskaia's subletter, Colonel Heizich. While the Colonel was ill in bed, his servant occupied a small room near the landing from which, he testified, he saw Maria unlocking the door to the empty half, and he saw Vul'f appear on the stairs and then follow Maria. Then he heard the door lock from inside, "some kind of noise began," and when he came closer, he heard a woman scream twice, and it sounded like Maria's voice. Yet, he walked away. At first he claimed that he believed Podolskaia to be present inside the locked rooms and that he "never suppos[ed] that Vul'f would do anything indecent," but when the court confronted him with the fact that he had seen Maria unlock the door, go in, then heard the door lock behind and thus must have known Podolskaia was not present, he admitted that he was simply "afraid to get involved in an evil affair." 55

All these servant witnesses depicted their floor of the building as divided into a domestic space made up of bedrooms and kitchens and an empty space that they took pains to make clear they would never enter. Analogous to the modern underground parking garage, this "empty space" takes on an aura of danger in their telling; it is the opposite of the safe, domestic space. ${ }^{56}$ The

51. Morgan and Rushton, Rogues, Thieves, 57.

52. Conley, "Rape and Justice," 525.

53. A schematic diagram of their floor of the building is included in case files, which was common in such cases. TsIAM, f. 16, op. 23, d. 1409, 1.12 ob.-13.

54. For these servants' testimony, see TsIAM, f. 16, op. 23, d. 440, 1. 6 ob. -9 ob.

55. For Ivanov's testimony, see TsIAM, f. 16, op. 23, d. 440, 1. 8 ob.-9 and d. 1409, 1. $18-19$.

56. After the rape, while Podolskaia was consulting with her daughter, Vul'f reappeared and was confronted at the door by the maid, Ekaterina. She was unable to prevent him from entering, but her presence did inhibit Vul'f from further assaulting Maria: he apparently begged her again to go with him to the Hermitage and offered her a box of candy, and she begged him to leave her alone. They spoke in French, so Ekaterina could not corroborate Maria's account of the words exchanged, but she did attest to the tone of 
empty space could also be viewed analogously to public spaces: it was not the private realm of any particular person and there is a seeming consensus that what happened there could not be controlled or predicted. And while the serf Ivanov eventually testified for Maria, it was only under pressure from the court; his initial response was that what took place in that empty space-the "evil affair"-belonged there, because the way to stay out of it was to walk away, literally and figuratively.

The presumed inherent danger of the "empty half" is in contrast to the domesticity of the inhabited section of the building, yet there are striking contrasts between the domesticity of this Moscow house and the better-known middle-class Victorian image of domestic space, with its aspirations to privacy for a nuclear family unit. ${ }^{57}$ Maria's Muscovite home was temporary, filled with people unrelated to each other, and crowded with unequal ranks. In his defense, Vul' $f$ had claimed that where the less wealthy lived in close quarters, it was perfectly respectable to socialize in a bedroom. The judges (of higher rank and greater exposure to western images of domesticity than any resident of Sretenskaia District) scoffed at this claim, yet when one recalls that Podolskaia's entire suite consisted of two rooms, of which one was a kitchen constantly occupied by a cook, it seems that Vul'f's claim was not unreasonable. Addressing a young unmarried woman in a bedchamber as Maria claimed he did (not to mention begging her for kisses), was certainly transgressive, but visiting Podolskaia in her only room was probably as typical for them as it was unimaginable to judges who could afford a front parlor.

This motley group of lower-middling and working people, including Podolskaia, Maria, Heizich, and the meshchanka cook and servants, can be seen as collectively working to defend the sanctity of the domestic space they shared, despite their inequality, lack of family ties, and the division of their space into apartments. ${ }^{58}$ This is interestingly similar, as a conception of space, to the Russian provinces, where in rural isolation gentry, townspeople and villagers necessarily defended their space from outsiders (perhaps most importantly the state) as well as from fire and other external threats despite internal conflicts and inequalities. ${ }^{59}$ Thus, rather than following a Victorian

their voices matching Maria's story. Having confronted Vul' $f$ at the door and been pushed aside, Ekaterina may have been especially supportive of Maria's story from a sense of having been insulted and threatened to a lesser degree herself. TsIAM, f. 16, op. 23, d. 440, 1. $7 \mathrm{ob}-8$.

57. In literature on rape in Britain, domestic space tends to be treated by historians only when it comes to crimes committed against servants by masters (masters were unlikely to be held accountable). See Conley, "Rape and Justice," 526. On alternative domestic spaces in a later period, see Terri Mullholland, British Boarding Houses in Interwar Women's Literature: Alternative Domestic Spaces (Routledge, 2016).

58. The maid Ekaterina was a serf but did not belong to Podolskaia; she was working for a salary, presumably paid to her master in the provinces as obrok. TsIAM, f. 16, op. 23, d. $440,1.6$ ob.

59. For more on the provincial Russian village in this light, see Antonova, An Ordinary Marriage, 47-73. This point is also illustrated by a "small but characteristic" case from 1890 narrated by Yekaterina Kozlinina. The case involved a young provincial woman who came to Moscow to complete her musical education and due to inexperience or lack of money stayed in the disreputable Hotel Montenegro. Its manager, Frolov, while drunk with friends, decided to visit his pretty lodger and tried to break through the locked door. 
bourgeois urban pattern as the state was attempting to develop, this social group better resembles the village transposed onto an urban building.

Together, court officials as well as the case's principals, servants, and other witnesses contributed to constructing or reinforcing a duality between an innocent Maria associated with the provinces, the closed world of the Institute, and domesticity, and a worldly, corrupt Vul'f associated with the city and public pleasure-seeking. Similarly, the crime was associated with an empty space but safety with the crowded quarters inhabited by guardian, ward, servants, and neighbors.

This duality persists in all the testimonies despite obvious contradictions: Maria actually grew up in Moscow, albeit in a cloistered institute, and must have hardly known the provinces. Her aunt and uncle demonstrated legal savvy in pursuing her case and successfully invoked high-ranking state officials on her behalf via her connection to the Institute, while Vul'f, though an urban official with a high-ranking brother, was apparently unable to use that or any other connection and made obvious mistakes in his handling of his defense. Nonetheless, for the participants in their trial, Vul'f remained the predator and Maria the embodiment of cloistered virtue.

It is probably not a coincidence that the courts and therefore the state, defining itself in this period by Emperor Nicholas I's Official Nationality, largely took Maria's side. Through associations with feminine innocence, modesty, and virtue, through the provinces as a "real" Russia, and through the imperial orphanage founded by the sponsor of Official Nationality himself representing the dominance of the autocracy in molding its subjects, Maria was in a sense "Orthodoxy, Autocracy, Nationality" in one. ${ }^{60}$ Vul'f, on the other hand, who was almost certainly a rapist, was from the judges' point of view also a perversion of the "imperial social project" to transform Moscow along modern and enlightened lines, exhibiting behavior that matched Russian perceptions of the dark underbelly of western urbanization..$^{61}$ None of these associations needed to be explicit in anyone's minds; rather, these tropes are what we already know was implicit for Muscovites of the time. What is significant are the ways these implicit associations affected real outcomes for people like Maria, and what such outcomes can tell us about the intersections of law and gender on the eve of Russia's most significant legal reform.

When Maria and her guardian initiated criminal proceedings against Vul'f, they engaged with a legal culture that many Russian novelists, playwrights, and memoirists-usually writing long after the Great Reforms-condemned

To escape him the woman jumped out of the window into the snow below and was injured. She was fortunate to be represented by Russia's leading defense lawyer, Fedor Plevako, who emphasized her willingness to risk her life rather than lose her honor. Frolov was convicted of abusing his authority and punished to the full extent of the law. See E. I. Kozlinina, Za polveka, 1862-1912 gg.: Vospominaniia, ocherki i kharakteristiki (Moscow, 1913), 359-62.

60. On Official Nationality, see Nicholas Riasanovsky, Nicholas I and Official Nationality in Russia, 1825-1855 (Berkeley, 1967); Andrei Zorin, By Fables Alone: Literature and State Ideology in Late-Eighteenth-Early-Nineteenth Century Russia (Boston, 2014), esp. 325-58; Wortman, “Ofitsialnaia narodnost' i natsional'nyi mif rossiiskoi monarkhii xix veka,” Rossia/Russia 3 (Moscow, 1999): 233-44.

61. Martin, Enlightened Metropolis, 5-6. 
for countless delays and opportunities for corruption. The court system originally created by Catherine's provincial reform of 1775 was criticized for being beholden to the provincial administration (to speak nothing of the tsar's personal authority), and thus lacking the autonomy required for the rule of law. It was also criticized for being fragmented across estate lines and for employing an archaic system of "formal proofs" that prevented judges from freely evaluating available evidence. The reform of 1864, according to this interpretation, was imposed upon a population that had little appreciation of, or need for, modern, liberal rule of law, despite the best efforts of an "enlightened" cohort of a few highly-educated officials. ${ }^{62}$

According to this traditional perspective on the development of legality in imperial Russia, the courts' ultimate failure to convict Vul'f would not be particularly surprising. The rigidity of the system of formal proofs combined with the usual prejudice against female victims often ensured that the criminal went free, as he did in approximately a dozen other rape cases from Moscow in the 1850 s and 1860s that we have examined. Conviction was not, however, impossible, according to official judicial statistics: the number of trials for sexual assault was lost in a sea of those for theft and illegal logging, but was roughly comparable to the number of trials for arson or counterfeiting and about one-third the number of murder prosecutions. The rate of conviction was lower than for the most common types of crimes but not exponentially so. ${ }^{63}$ It was not unthinkable even for elite men to be sentenced to Siberian exile or hard labor for sexual assault. For example, in 1856 a 32-year old nobleman and former chancery clerk from Kiev Province, Kazimir Fogel, was convicted of raping a 17-year old peasant girl and sentenced to eight years of hard labor after the case moved through every step of the court hierarchy all the way to the Council of State. While in Siberia, he managed to get the governor general, the renowned Count Nikolai Muraviev-Amurskii, to intercede on his behalf with the chief of the Third Section, Russia's political police. Fogel's allegations that the girl had withdrawn her complaint turned out to be unsubstantiated, however, and he remained in Siberia, although later, in 1861, pursuant to Muraviev's "special petition," Fogel was transferred from hard labor

62. On the 1864 reform and the development of legality in Russia, see Richard S. Wortman, The Development of a Russian Legal Consciousness (Chicago, 1976); Jörg Baberowski, Autokratie und Justiz: Zum Verhältnis von Rechtsstaatlichkeit und Rückständigkeit im ausgehenden Zarenreich 1864-1914 (Frankfurt am Main, 1996). On pre-1864 legal practice, see Sergei Antonov, Bankrupts and Usurers of Imperial Russia: Debt, Property, and the Law in the Age of Dostoevsky and Tolstoy (Cambridge, Mass., 2016) and, for an earlier period, John P. LeDonne, Absolutism and Ruling Class: The Formation of the Russian Political Order, 1700-1825 (New York, 1991).

63. For a discussion of rape in rural Russia in the post-reform period see Stephen P. Frank, Crime, Cultural Conflict, and Justice in Rural Russia, 1856-1914 (Berkeley, 1999), 159-66. Frank notes that sexual crime was widespread but rarely prosecuted. According to official statistics for 1860, there were 2,133 men prosecuted for "violating a woman's honor," as compared to 3,282 men tried for arson, 3,085 for counterfeiting, 8,046 for murder, and 124,724 men for theft. See Statisticheskii vremennik rossiiskoi imperii. Vol. 1 (St. Petersburg, 1866), otd. III, 6. The numbers for convictions were 228 for rape (10.7\% rate), 499 for arson (15.2\%), 132 for counterfeiting (4.3\%), 1,283 for murder (15.9\%), and 19,440 for theft (15.6\%). Ibid., 10. 
to the regular penal settlement. Fogel was perhaps disadvantaged by being a Catholic of Polish descent, yet he managed to get one of Russia's most influential statesmen to intercede on his behalf; moreover, his victim was a peasant. This case shows clearly the extent of possible outcomes for Vul'f. ${ }^{64}$

The reason Vul'f came so close to being convicted and sentenced to hard labor was that several important formal hurdles that normally undermined prosecution were met: the victim complained right away, there was a prompt medical exam that uncovered signs of violence, and there was at least one witness to the attack. Therefore, this case involved a more thorough deliberation and consideration of all the factors contemplated by the law than seems to have been the norm in sexual assault and other criminal cases of that period, and in this sense it can be regarded as an "ideal" pre-reform legal case despite its disappointing outcome. Finally, even the court's ultimate failure to convict Vul' $f$ should not be seen as a complete lack of punishment, as we will see. In sum, the case presents pre-reform law as a more sophisticated system than it is traditionally considered to be, suggesting that the reform of 1864 was much less of a revolutionary break with existing practice or with existing attitudes toward the law..$^{65}$

For the judges of Moscow's fist-tier Aulic Court (which handled cases involving government officials without any landed property in Moscow), the starting point of their inquiry was the text of the Penal Code of 1845, in force until the end of the imperial period. Unlike English criminal statutes, which defined rape as "the carnal knowledge of a woman forcibly and against her will," Russian law did not provide a single definition. Virtually the only relevant provision was Article 312, which listed the requirements for a rape conviction as (1) "precise determination that the violation actually occurred"; (2) "when there will be witnesses to the fact that the victim cried for outside help"; (3) "when either she or the accused, or both, will have bloody signs, bruises, or torn clothing testifying to the victim's resistance; (4) when the report will be submitted immediately, or before the end of the day." 66 These requirements were not particularly surprising or "backward"; they were found in other legal systems as well (although in an uncodified form in nineteenth-century English or U.S. law). Particularly common to western legal systems was the requirement that a rape victim had to actively resist the attacker-although the extent of this resistance was gradually relaxed over the course of the century-and that she report the attack as promptly as possible and be subjected to a physical examination. The attacker was also supposed to be examined but that did not always happen.

The second set of applicable laws were Russia's evidence rules, which required either a confession or sworn testimony by two witnesses for criminal

64. GARF, f. 109, op. 90, d. 557. Even for sexual crimes categorized as non-violent, Siberian exile was a real possibility. For instance, in 1867 art teacher Andrei Vyrypaev was sent to penal settlement in Siberia for deflowering his stepdaughter, GARF, f. 109, op. 95, d. 329.

65. For a more general argument partially “rehabilitating” pre-1864 law, see Antonov, Bankrupts and Usurers.

66. Svod Zakonov Rossiiskoi imperii: Zakony ugolovnye, Vol. 15 (St. Petersburg, 1857), 2: Art. 312. 
conviction ${ }^{67}$ These rules have traditionally been criticized as depriving judges of the opportunity to freely evaluate available evidence. It is possible to imagine a more modern evidence system in which Ivanov's testimony alone could have swayed a judge, and perhaps even more likely, a jury to convict Vul'f. As it was, the fact that only one witness was available-remarkable enough for a rape prosecution-failed to amount to the "perfect" proof required for conviction. There were two other relevant rules of evidence, however: Article 327 stated that "a personal examination conducted on the place of the crime and confirming the occurrence of that event" had the same probative power as witness testimony; Article 328, moreover, stated that testimony by medical officials was considered to be "perfect" proof. ${ }^{68}$

In this case, the police investigation of physical evidence, and their questioning of witnesses, was remarkably thorough, but accompanied by a few mistakes that undermined the prosecution. The first step was a physical examination of Maria by obstetrician von Wendrich and Tver' Precinct midwife Simonova. ${ }^{69}$ Their examination concluded that Maria had certainly lost her virginity recently. There were no signs of violence on her legs or abdomen, which might explain why the doctor did not bother to examine the rest of Maria's body and allowed her to put her undergarment back on and wear it home. Instead, the doctor's report emphasized signs of Maria's age: he thought he was investigating a case of "defloration," or criminal sexual intercourse with a minor. ${ }^{70} \mathrm{He}$ reported that Maria was seventeen years old (later investigation would reveal she was actually nineteen) and described her still-not-fully-developed secondary sexual characteristics to support his estimation of her age. ${ }^{71}$

However, the police were dissatisfied because the obstetrician did not examine all of her body. A few days later Maria was reexamined by a police doctor, Spassky, to look specifically for any other signs of violence. This doctor found a bluish-yellowish bruise on the front of her right arm, and a "reddish oval swelling" on her back. ${ }^{72}$ Examination of the room where Maria alleged the rape occurred found that these marks fit "completely" the corner of the dresser and a wooden bolster on the back of the bed and that the placement and appearance of the wounds was consistent with the way Maria described being pushed and the time she alleged the rape had occurred. Police officers also tested whether it was possible for her to knock and scream without being

67. Svod Zakonov, vol. 15/2 (1857), Art. 316-48.

68. On medical experts before and after the Great Reforms, see Elisa M. Becker, Medicine, Law and the State in Imperial Russia (Budapest, 2010).

69. TsIAM, f. 16, op. 23, d. 440, 1. 5; d. 1409, 1. 3-6, 12 ob., 29 ob.-32.

70. The tearing of the hymen in a girl under fourteen (the age of consent) was in itself a prosecutable crime ("rastlenie") after 1845. By all the various estimates given to the court, Maria was of age and therefore the fact that she had been a virgin could be considered only as aggravating a crime of rape, and to prove rape the victim had to prove that she had resisted intercourse. As Laura Engelstein has discussed at length, the meaning of the various legal terms related to rape were under considerable debate in the nineteenth century, invoking as they did a variety of cultural assumptions and attitudes about women's status, chastity, and legal rights. See her "Gender and the Juridical Subject."

71. TsIAM, f. 16, op. 23, d. 1409, 1. 3.

72. TsIAM, f. 16, op. 23, d. 440, 1. 5 . 
heard by the other occupants of the building and found that this, too, was consistent with Maria's story. ${ }^{73}$

In sum, the law applicable to this case presented the courts with numerous problems of interpretation and application, even though judges in Russia, as in other Continental legal systems, were explicitly expected to avoid anything more than direct and literal application of the statutes according to their plain meaning. Vague and confusing statutory language is not unique to Russia, however. In Victorian Britain, for instance, the law of rape was so "vague" that, according to Conley, "[c]onviction rates had more to do with popular male attitudes than with legal codes." ${ }^{74}$ At least formally, English juries and judges were free to consider such issues as the victim's and the attacker's social status, character, and respectability, as well as how vigorously the victim attempted to fight back; in Russia, judges were officially prohibited from considering any factors not listed in Article 312. Needless to say, this formal prohibition did not mean that judges would not be personally influenced by the victim's character or other extraneous factors. Moreover, the supposed rigidity of Russian "formal" proofs could not in practice eliminate judges' discretion and analysis of available evidence. ${ }^{75}$

This was especially true, in cases of rape, of the medical exam and medical testimony regarding signs of violence. In Maria's case, the doctor who conducted the initial examination made a significant omission in not examining her back, where the bruises from the attack were located. Several days later, when another exam took place to remedy the omission, the bruises were already less obvious, causing the judges to question the degree of violence employed by Vul'f. Thus, even before the reform, Russian criminal procedure was a site of contestation, negotiation, and interpretation, though more formalized in some aspects than its English counterpart.

This contestation was apparent at each level of Russia's three-tiered judicial hierarchy. The Aulic court made the initial ruling, which rejected all the evidence against Vul'f, acquitted him of the rape charge, and left him "under suspicion" (in effect amounting to probation) on the defloration charge. The decision referred to Vul'f's "name [meaning honor] and service [record]," which would both be blemished if he were not acquitted..$^{76}$ Podolskaia was left "under suspicion" of inciting Il'ina to charge Vul'f with rape and organizing the rendezvous. Although Podolskaia would not be imprisoned, she was to be prohibited from residing in either of Russia's two capital cities. This is essentially the likely outcome had Vul'f's case been tried by an English jury (in other words, in the scenario considered ideal by most critics in the late nineteenth century and now): Vul'f's honor was of paramount concern, and Il'ina was presumed to have colluded with Podolskaia to falsely charge Vul'f. ${ }^{77}$ But

73. TsIAM, f. 16, op. 23, d. 440, 1. 5-5 ob.

74. Conley, "Rape and Justice,” 536.

75. On judges' discretion under the system of formal proofs, see Antonov, Bankrupts and Usurers, 302-8.

76. TsIAM, f. 16, op. 23, d. 1409, 1. 37-38.

77. There was no allegation of blackmail but it is a persistent western cultural myth that women often make rape allegations to blackmail men. See Antony E. Simpson, "The 'Blackmail Myth' and the Prosecution of Rape and its Attempt in $18^{\text {th }}$ Century London: The 
since the trial was conducted by a panel of judges, one of the members, Klark (ironically, an English-derived name), registered a dissent-something that we did not know Russian lower-level pre-reform judges ever did-arguing that Vul'f should have been left "under suspicion" of rape because of Maria's bruises and Ivanov's witness testimony, and, equally importantly, that he was not to be freed from arrest pending further proceedings. Moreover, Moscow's Procuracy official protested the decision, as did another Aulic Court member, Kerzelli, who replaced Klark after he became sick before the final decision. Kerzelli wanted to convict Vul'f of rape and sentence him to hard labor. On October 15, 1859, the court voted to forward the case to the next level of the judicial hierarchy and to keep Vul' $\mathrm{f}$ in prison. ${ }^{78}$

Moscow's Chamber of Criminal Justice was the most important element in the court hierarchy: staffed by trained judges, it reviewed all criminal and civil cases of any importance, making the first-tier courts little more than its appendages for dealing with preliminary issues. Before the Chamber's judges made their ruling, they demanded considerable additional information about all parties to the case. This included questioning of Vul'f's neighbors and acquaintances about his character and behavior, and even of Elizaveta Polevaia, the headmistress of the Institute, who was blamed for having surrendered Maria to a mere acquaintance, Podolskaia. Polevaia would lose her position in $1861 .{ }^{79}$

The majority of the judges ruled that Il'ina was raped, basing their decision on several factors: the medical testimony and physical examination proving that a violent attack took place, the fact that Vul'f was alone in the apartment with Maria, that her cries were heard by a witness, Ivanov, after Vul'f had followed her to the room, that Podolskaia and the two servants saw Il'ina coming back red-faced and frightened, and finally attestations of Il'ina's modest behavior and of Vul'f's insolence. ${ }^{80}$ In April 1860, Vul' $f$ was sentenced to be stripped of his rights as a nobleman plus six years of hard labor, with subsequent settlement in Siberia. ${ }^{81}$ Podolskaia was acquitted of arranging the crime, and Vul' f's property was to be used to support Il'ina "with the means appropriate to her station until her marriage." 82 We have no information about the judges' deliberations, but it appears they thought that the requirements of "formal proofs," which privileged medical testimony, coincided with a more "modern" perspective on the law that took into evidence what amounted to less than "perfect" proof, such as Il'ina's reputation and her behavior after the attack, and Ivanov's testimony. Of course, another possibility was that

Creation of a Legal Tradition,” The Journal of Criminal Law \& Criminology 77, no. 1 (Spring 1986): 101-50.

78. TsIAM, f. 16, op. 23, d. 1409, 1. 37-39.

79. TsIAM, f. 16, op. 23 , d. $1409,1.39$ ob. -40 .

80. TsIAM, f. 16, op. 23, d. 1409, 1. 48 ob. -53.

81. Svod zakonov, vol. 15/1 (St. Petersburg 1857). Article 2078 prescribed that a person convicted of raping a woman or a maiden over fourteen years of age be stripped of his estate privileges and sentenced to between four and eight years of hard labor and, if eligible, be subjected to corporal punishment and branding. This punishment was severe, but it generally corresponded to punishments for non-sexual assault and physical injury, rather than such crimes as arson (which entailed up to 15 years with aggravating factors), counterfeiting (up to 10 years), or homicide (could result in a life sentence of penal labor).

82. TsIAM, f. 16, op. 23, d. 1409, 1. 54. 
the judges were attuned to the fact that the most important people in Moscow wanted Vul' $\mathrm{f}$ punished. As in the lower-court ruling, the Chamber's decision also included a dissenting opinion, by Councilor Mikhailov, who argued that in order to convict Vul'f it would have been necessary to show more physical damage than was apparent from the physical examination.

The next step following this conviction was to submit the decision to Moscow's governor, Pavel Tuchkov, who approved the sentence and forwarded the case to Russia's highest court, the Governing Senate, as was required for all cases when a noble was sentenced to be stripped of his or her legal rights. ${ }^{83}$ The Senate's decision took over a year, finally issued in June $1861 .{ }^{84}$ The Senate disagreed with the Chamber's interpretation of the medical evidence and ruled that it did not prove that violence had occurred, despite the conclusion by the Medical Office that Maria's bruises "without a doubt came from outside violence." ${ }^{85}$ The decision discussed all the other evidence against Vul'f listed in the Chamber's ruling but refused to hold that the combination added up to proof of Vul'f's guilt. The Senate therefore ruled to leave Vul'f "under strong suspicion" of rape combined with defloration and to acquit Podolskaia because Il'ina had not made a claim against her.

It is conceivable that only five years later the introduction of a jury trial and the abolition of "formal proofs" would have resulted in a very different outcome, because a jury would be free to consider and evaluate all available evidence. Late-imperial jurors could convict a rapist on much less evidence, for example, when the victim had committed suicide, which is what happened in 1890 in one of Russia's most prominent criminal trials, involving the rape of a young actress, Yelizaveta Cheremnova, by notary public Nazarov. ${ }^{86}$ But it is also possible that Vul'f could, in such a situation, employ a skillful defense attorney and convince the jurors of his innocence. After all, English cases of rape were heard by trial juries for centuries without any noticeable impact as compared to Russia's non-public and mostly-written system (in particular, the fact that Vul'f was acquainted with Maria and technically was invited into the house would heavily lean towards an acquittal). At least in Britain, it was the increased attention of the press and subtle changes in the law (such as the relaxation of the requirement that a victim forcefully resist the attacker) that made rape prosecutions more successful towards the end of the nineteenth century. ${ }^{87}$

Although Vul'f escaped his initial sentence of hard labor, his punishment was far from symbolic. First, he was kept in prison for the duration of the investigation-something that rarely happened in other Russian rape cases from the period, to say nothing of Victorian England. Second, being left under "suspicion" meant that Vul'f would be officially considered a troublemaker subject to police surveillance for the rest of his life and would be virtually excluded from civic activity. It is unlikely that he would ever have been permitted to live in Moscow after attracting such negative attention from the

83. TsIAM, f. 16, op. 23, d. 1409, 1. 66.

84. TsIAM, f. 16, op. 23, d. 1409, 1. 71-90.

85. TsIAM, f. 16 , op. 23 , d. $1409,1.31$ ob.-32.

86. See Oberländer, "Shame and Modern Subjectivities"; Anatolii F. Koni, Sobranie sochinenii v 8 tomakh, vol. 3 (Moscow, 1967), 427-47, 510-13.

87. Wiener, Men of Blood, 89. 
city's governor. Moreover, he would likely experience problems with future government service, respectable marriage, obtaining credit, purchasing property, or participation in local elections. Finally, Vul'f's honor as a nobleman was ruined, perhaps to the same extent that he ruined the honor of his victim. Although there were no public newspaper reports and no public trials in Russia in 1860, Vul'f's house and even his dirty underwear were searched by the police, and his servants and neighbors were questioned regarding his possible propensity to attack young girls or engage in other suspicious behavior. The fact that Vul'f could not produce any testimony vouching for his respectability and good character, even from his relatively powerful brother, would also have influenced his reputation among his neighbors and peers.

We have used three images echoed in the testimony from this trial as lenses to understand the actions of participants and, ultimately, how this case reflects wider concerns among recently transplanted, lower-middling-status Muscovites on the eve of Russia's Great Reforms and in response to the urbanization and other cultural transformations underway at mid-century. We conclude that notions of women's honor were used to advantage by Maria and her supporters, and by the courts, in a concerted attempt to convict both her attacker and (on the courts' part) the woman responsible for Maria's safety at the time of the attack. Despite these efforts and, on the whole, the sympathy of the courts, the rule of law ultimately carried greater weight, a perhaps unexpected outcome in pre-Reform courts. ${ }^{88}$

Had the case been tried after the Reform, a journalistic narrative would have taken the place of Maria's and that of the other witnesses or been embellished from those accounts. It is possible that newspapers would have seized on Vul'f's having been previously acquainted with Maria to discredit her accusation, as was common elsewhere. Alternatively, given the salacious nature of Podolskaia's marital situation and a reading public's craving to assign blame, it is reasonable to expect that had the trial been public, Maria might have been portrayed as the innocent pawn and Podolskaia would have been convicted at least in the court of public opinion, if not the law. ${ }^{89}$ Thus it is difficult to guess how either a jury or publicity might have altered the outcome had the case been tried under the new system, but either way, the case suggests that the judicial reform cannot be said to have brought a superior modern legality ex nihilo.

In sum, the Il' ina case challenges a simplistic narrative of arbitrary prereform courts and post-reform rule of law. Following Alexander Martin's pessimistic view of the Imperial social project's outcome, this case suggests that instead of creating an urban middle social strata the culture of the village was

88. Unexpected, that is, to contemporary critics then absorbed in the Reform project and to subsequent historians who have accepted their narrative of pre-Reform corruption and arbitrariness and relatively unproblematic rule of law after it rather uncritically. That narrative is being challenged in recent works, however. See Antonov, Bankrupts and Usurers, Marrese, A Woman's Kingdom, and Kollmann, Crime and Punishment.

89. On press reactions to scandalous public trials after the Great Reforms, see Louise McReynolds, Murder Most Russian: True Crime and Punishment in Late Imperial Russia (Ithaca, 2016), and Oberländer, "Shame and Modern Subjectivities" and Unerhörte Subjekte. 
transplanted, at least in some cases and degrees, to lower-middling Moscow neighborhoods. Finally, notions of feminine virtue deriving both from longstanding religious associations and then-developing domesticity allowed an ordinary young woman like Maria Il'ina to pursue justice arguably more effectively than she might have had she been attacked in an empty room in London or Paris. 